\title{
DOES CAPITAL ADEQUACY INFLUENCE THE FINANCIAL PERFORMANCE OF LISTED BANKS IN NIGERIA?
}

\author{
Arekhandia Alfred Ukinamemen, Hassan O. Ozekhome* \\ Department of Accounting \& Finance \& Department of Economics, Samuel Adegboyega \\ University, Ogwa- Edo State, Nigeria. \\ adiaukis@gmail.com \\ hassanozeks1@gmail.com
}

\begin{abstract}
Capital adequacy is important for the effective operation of any institution, particularly, its sustenance, viability and future growth. Banks as core financial institutions require sufficient capital base for its fund requirement and needs. Against this premise, banks and other financial institutions must keep balance between capital and available risk in its assets in order to reduce the likelihood of systemic crises, financial fragility and thus guarantee stability. This study empirically examines the impact of capital adequacy on the financial performance of banks in Nigeria. A sample of ten (10) listed banks on the basis of size and availability of data were examined over the period 2010 to 2017, using descriptive statistics, and multivariate panel data estimation technique, after conducting the Hausman, test of correlated random samples, wherein the fixed effect model was selected as the appropriate model. The empirical results revealed that banks' capital adequacy ratio has a positive and significant impact on the financial performance of banks in Nigeria. Other variables found to be significant in the determination of the financial performance of banks in Nigeria are; bank size, bank loans and advances, debt ratio and growth rate of output. Against the backdrop of these findings, we recommend amongst others; sufficient capital base for banks, increased bank size through economies of scale measures, efficient deployment of bank resources, increased economic output (economic productive capacity) that will stimulate bank performance. These, will, in no doubt, reduce banks' vulnerability to systemic crises and consequently enhance their stability for national growth through efficient financial intermediation.
\end{abstract}

Keywords: Capital adequacy, financial performance, Risk weighted assets, Panel data.

JEL classification: E44, G21 G28, 016

\section{Introduction}

A strong capital base is critical to the financial health and viability of any bank. As the corner stone of bank's strength, it is the most widely used parameter and indicator for measuring bank's performance. In this regard, the capital adequacy of a bank determines the reliability and healthiness of the bank, as it serves as a safety buffer against unanticipated losses, particularly systemic crises (Singh and Milan, 2018). The sufficiency of banks capital or adequacy is determined by capital adequacy ratio. Capital adequacy thus refers to the determination of banks existing capital structures, in terms of the ability weld against potential widespread risk, crisis and distress. Banks' capital adequacy influence bank performance, since the adequacy of by implication determines the amount of funds available for banks' business and other profitable initiatives and the degree of absorption of risks (Singh and Milan, 2018).

\footnotetext{
* Corresponding author: Hassan O. Ozekhome
} 
Given the bitter experiences of past financial crises and in the Nigerian banking industry against the backdrop of weak capital adequacy, and the resultant effects which left trails of woes for, depositors, investors, shareholders, and the general economy, there is no doubt, that the health and safety of the entire banking system depends on the capital adequacy. It is in recognition of this that a number of bank reforms, particularly aimed at increasing the capital base of banks have been launched. In general, banking crisis can be triggered by the preponderance of weak banks characterized by persistent illiquidity, insolvency, under-capitalization, high level of non-performing loans and weak corporate governance among others, as in the Nigeria case (Uchendu, 2005). Since the sufficiency or adequacy of banks' capital is directly related to its performance, a study of this nature, which empirically seeks to investigate the nexus between banks' capital adequacy and banks' performance in Nigeria, is very sacrosanct.

There is scarcity of empirical evidence on the effect of bank's capital adequacy on the performance of banks in Nigeria, within the context of the Basel standards. In addition, the few related studies only examined the impact of bank capital base on the performance of banks, using a battery of bank internal asset and efficiency variables, without taking into cognizance the effect of macroeconomic environment on the capital adequacy- bank performance nexus. The recognition of these obvious gaps necessitates this study.

In the light of this, the following hypotheses are tested in this study:

(i) There is no significant relationship between capital adequacy of banks and bank financial performance in Nigeria.

(ii) Capital adequacy has no significant impact on the financial performance of listed banks in Nigeria.

Aside the introductory section, the paper is organized as follows. Section two consists of literature review which considers key theoretical, empirical and policy issues associated with capital adequacy and financial performance of banks. Section three contains the methodology, model specification and data, while section four presents the empirical results and analysis. The conclusion and policy recommendations are presented in section five.

\section{Literature Review}

\subsection{Theoretical Issues}

Capital adequacy is a measure of the sufficiency of banks' capital base against their vulnerability to widespread risk, crisis and distress. As a financial liquidity mechanism, it is used to protect depositors and promote the stability and efficiency of financial system, by helping to prevent excessive leverage and insolvency of banks. High capital adequacy, as a financial cushion helps to minimize incidence of non-performing loans. Thus, banks with high capital adequacy ratio face lower bankruptcy, funding costs and illiquidity problems, which are the precipitating factors of systemic crises. The adequacy of banks' capital thus, determines health and virility of banks. Thus, when banks have weak capital adequacy ratio, it is a direct signal of impending financial crisis. Capital adequacy can be measured in a number of ways, however, the most widely used measure is Capital to Risk-Weighted Assets Ratio (CRAR).

\section{Capital Adequacy and Banks' Supervision and Regulatory Framework}

The Bank Supervision and Regulation committee approved the international accepted norms for capital adequacy standards, developed by the Basel Committee on Banks Supervision (BCBS). BCBS initiated Basel I norm in 1988, considered to be the first step toward risk weighted capital adequacy norms. Basel I is a framework for calculation of "Capital to Risk-Weighted Assets Ratio (CRAR)". It defines a bank's capital as two types: Core (or tier I)- which includes paid-up capital (ordinary shares), statutory reserves, 
perpetual non-cumulative preference shares eligible for inclusion as tier-I capital, subject to laws in force from time to time. Innovative perpetual debt instruments and capital reserves representing surplus arising out of sale proceed of assets. Under Basel I, at least 50 percent of a bank's capital base should consist of core capital. Supplementary (or tier-II) capitalinclude undisclosed reserves, revaluations reserves, hybrid capital instrument, general provisions and loss reserves, subordinated debt and investment reserve account. Supplementary capital absorbs losses in the event of winding up and thus provides lesser degree of protection to its depositors.

\section{Basel II Accord}

Basel II Accord, came into operation in 2004, being a revision of Basel I. Under the Basel critical aspects, namely; Minimum Capital Requirement- calculated to include credit, market and operational risks; Supervisory Review-providing key principles for reviewing, risk management guidance and supervisory transparency and accountability, and Market II Accord, credit risk includes market risk. In addition, operational risk is taken into cognizance in the calculation of capital adequacy ratio. The Basel II Accord focuses on three Discipline, which focuses on discipline by developing a set of disclosure requirements that allow market participants assess key information on risk exposure, risk assessment process and capital adequacy of a bank (Singh and Milan, 2018).

\section{Basel III}

The financial crisis of 2008 was the propelling force behind the introduction of the Basel III guidelines released in December 2010. It was motivated by the need to further strengthen the system as banks in the developed economies were under-capitalized, over-leveraged and had a greater reliance on short term funding. Also, the quantity and quality of capital under Basel II were deemed insufficient to contain any further risk. Under Basel III, the minimum capital adequacy ratio banks must maintain is $8 \%$, also known as Capital to Risk (Weighted) Assets Ratio (CRAR). The rationale is to promote a more resilient banking system by focusing on four vital banking parameters, namely: capital, leverage, funding and liquidity. The Basel III capital requirement would also have a positive impact for banks, as it raises the minimum core capital stipulation, introduce counter- cyclical measures, and enhances bank's ability to conserve core capital in the event of stress thought a conservation capital buffer. The stipulated liquidity requirements, on the other hand, would bring in uniformity in the liquidity standard followed by the banks globally. This liquidity standard requirement would be of immense benefit to Nigerian banks to manage liquidity pressure in a stress scenario more effectively.

\subsection{Theoretical Review}

The role of financial sufficient capital base in enhancing efficiency and performance of banks is replete in the finance literature by leading finance-growth theorists such as Mckinnon (1973) and Levine (2005). In line with their position, good capital base helps to prevent systemic financial crises, illiquidity and solvency problems, and consequently enhance the performance of banks. The relationship between capital base and performance show that efficiency in financial intermediation, monetization and capital formation determine bank viability and stability and performance (Imala, 2005). It therefore follows that that well-capitalized banks face lower bankruptcy, funding costs and illiquidity problems and are usually insulated from financial crises enabling them perform their financial intermediation function of resource mobilization and credit channeling to the real sector of the economy (Levine, 1997).

Boyd and Runkle (1993) buttressing this, argued that well-capitalized banks are more profit-efficient and susceptible to lower fragility. This is against the backdrop that the high capital base arising provides a buffer against adverse shocks and unanticipated financial 
crises. Studies on financial liberalization, development and fragility further gave credence to the imperative for high capital adequacy by drawing from the model used by Demirguc-Kunt and Levine (2003) which posits a strong positive correlation between bank capital and efficiency. The model established the existence of a positive correlation between financial bank capital and its performance. It maintained that sufficient capital base will not only enhance performance of banks, but will ginger the economy through efficient financial intermediation.

\subsection{Empirical Review}

Few studies have examined the impact of capital adequacy on bank performance. A review of the pertinent studies is presented in this sub-section.

Ezike and Oke (2013) investigate the empirical nexus between capital adequacy standards, Basel accord and bank performance, using evidence from Nigeria. Using data covering the period 2003 to 2007, and ordinary least variables technique, the findings show that capital adequacy standards exert a major influence on bank performance. They however recommend the CBN no to rely solely on the capitalization of banks as a determination of bank performance.

Olalekan and Adeyinka (2013), assess the effect of capital adequacy on deposit money banks' profitability, using empirical evidence from Nigeria. The study, in particular assesses the effect of capital adequacy of both foreign and domestic bank in Nigeria and their profitability. They used primary data collected from 76 structured questionnaires involving sand secondary data collected from banks statements (2006-2010). The findings of the primary show a non-significant relationship, but the secondary data analysis showed a positive and significant relationship between capital adequacy and profitability of bank. This implies that for deposit-taking banks in Nigeria, capital adequacy plays a critical role in the determination of profitability.

Enoch (2013) examines the effect of bank recapitalization on the performance efficiency of banks, in terms of lending to the real sector of economy. He used the Twenty-two banks that finally emerged from the recapitalization exercise were used for the study. Structured questionnaire was administered to two top echelons of each bank and data collected was analyzed with using correlation and regression analysis. The findings show that bank recapitalization has stimulated the ability and efficiency of banks to lend to the productive sector of the economy. The study therefore recommended that the exercise should be review in the future to keep peace with trend.

Kumar and Nazeen (2014) investigate the impact of capital adequacy on the performance of the Indian private sector banks. Employing panel data analysis, the evidence show that capital adequacy has a positive and significant impact on the financial performance of private banks.

Nikhat (2014) examines the relationship between the adequacies of capital as a financial soundness indicator for banks. Using various components of regulatory capital in line with Basel's norm in respect to minimum capital requirements for banks, and a trend analysis for the top ten commercial banks in India, the author finds that banks with the highest CAR are able to withstand financial crises.

Mathur (2015) examines effect of capital adequacy norms on the banking sector in India. Employing panel data methodology, the findings show that capital adequacy norms have positive operational effect on banking sector performance. Against the background of this finding, she recommends sound regulatory policy on capital base for banks.

Agbeja, Adelakun and Olufemi (2015) investigate the link between capital adequacy ratio and bank profitability, in Nigeria. In particular, the study sought to empirically investigate whether or not capital adequacy ratio affects banks profitability, its effect on loans and advances and bank profitability, as well as the impact of capital adequacy on bank's exposure to credit risk. They use secondary data for the analysis, which covered the period 
2010-14, and multivariate regression analysis. The empirical results show a positive and significant relationship between capital adequacy and bank's profitability, suggesting that banks with more equity capital invariably have higher financial safety, and such advantage implies higher profitability. Against the backdrop of these findings, they recommend that deposit money banks in Nigeria be made to have minimum capital base to the optimal level in order to enjoy assess to cheaper sources of funds with subsequent improvements in profit levels.

Torbir and Zaagha (2016) examine the impact of capital adequacy measures on bank financial performance in Nigeria using a co-integration technique and granger causality test approach. The empirical findings revealed the existence of significant long run relationship between bank financial performance variable and capital adequacy indicator in the Nigerian banking industry. The granger causality test results reveal that there is unidirectional causality flowing from the ratio of shareholder funds to bank total assets. The Causality also shows evidence of a feedback relationship from the ratio shareholders fund to return assets in Nigerian banks. These findings suggest that capital adequacy significantly influence the financial performance of banks in Nigeria.

Singh and Milan (2018) investigate the impact of capital on banks financial performance in India in two different sub-periods of 2012-13 to 2016-17, employing ANOVA and multivariate analyses. The results show that private sector banks performance is positively and significantly related to capital adequacy. On the other hand, public sector banks performance is found to be moderate correlated with capital adequacy but its impact on banks performance not effective.

Edeh (2018) empirically examines the nexus between capital adequacy and performance of private and public banks in Nigeria. A sample of ten (10) banks consisting of seven private and three public banks was examined between 2012 and 2017, using return on equity as measure of bank performance. The multivariate panel least squares estimation technique was used. The empirical results revealed that capital adequacy ratio has a significant positive effect on the performance of private banks in Nigeria, while the effect on public sector banks is positive but weak. Apparently due to the fact that the capital adequacy ratio (CAR) tier capital is higher than private sector banks, and most often government-determined. Against the backdrop of these findings, the author recommends that strong institutional, regulatory and supervisory and measures be put in place to minimize the incidence of non-performing loans and the resultant near- financial crisis-situation, so as to make banks more virile to support national development.

\section{Methodology}

\subsection{Population and Sample}

The population of this study is the entire banking industry in Nigeria, compose of 23 listed banks in the Nigerian Stock Market since the study borders on the establishing the relationships between capital adequacy and financial performance of banks in Nigerian. A sample of ten (10) selected banks on the basis of size and data availability are selected for empirical examination. The banks include, Access Bank Plc, Diamond Bank Plc, ECO Bank Plc, First Bank Nig. Ltd, First City Monument Bank (FCMB), Guarantee Trust Bank (GTB), Sterlin Bank Plc, United Bank for Africa (UBA), Union Bank Plc, and Zenith Bank Plc. The selected panel of banks are the ten biggest banks in Nigeria, known as the 'big 10' and constitute about 85.2 of the total assets of banks in Nigeria. The period for the study is seven (8) years covering 2010 to 2017. 


\subsection{Variables Description}

In this study, the Return on Asset (ROA) is used as financial performance indicator-measured as earnings before interest and taxes (EBIIT). Its selection is based on its ability to appropriately capture banks performance from the perspective of efficiency of assets. The independent variables are capital adequacy ratio (CAR), measured as Risk weighted assets ratio, bank size (BS), measured as total assets of banks and debt ratio (DR), measured as sum of short and long term debt to total assets (leverage) ratio, bank loan and advances (BLA) - measured as total loans and advances and growth rate of a real GDP (GRGDP-real output capacity of the economy) - a measure of the impact of the macroeconomic environment on bank performance.

\subsection{Model Specification}

The model specified in this study demonstrates that bank' financial performance (ROA) is a function of CAR, BS, BLA, DR and GRGDP. The functional form of this model will be thus expressed as:

$R O A=f(C A R, B S, B L A, D R, G R G D P)$

Where: $R O A=$ Return on asset

$\mathrm{CAR}=$ Capital adequacy ratio

$\mathrm{BS}=$ Bank size

$\mathrm{BLA}=$ Bank loan and advances

$\mathrm{DR}=$ Debt ratio (or leverage)

GRGDP $=$ Growth rate of real GDP

The econometric form of the model can be specified as:

$R O A_{i t}=\alpha_{0}+\alpha_{1} C A R_{i t}+\alpha_{2} B S_{i t}+\alpha_{3} B L A_{i t}+\alpha_{4} D R_{i t}+\alpha_{5} G R G D P_{i t}+\varepsilon_{i t} \ldots \ldots$.

Where all the variables are as earlier defined.

$\varepsilon_{i t}=$ random error term

The apriori expectations in the model are: $\alpha_{1}, \alpha_{2}, \alpha_{3}, \alpha_{5},>0 ; \alpha_{4}><0$.

\subsection{Method of Estimation}

The model specified in (2) is based on the panel regression analysis procedure that is adopted in this study. The main advantage of the panel data analysis is that it comprehensively takes the individual characteristics of the different firms used in the study. It is generally observed that firm-level behaviour is a strong factor in the determination of dividend policy and hence, this differentiation may bring endogeneity bias into the estimation. The panel data analysis helps to correct this inherent estimation problem. The basic class of models that can be estimated using panel technique may be written as:

$$
Y_{i t}=f\left(X_{i t}, \beta\right)+\delta_{i t}+\gamma_{t}+\epsilon_{i t} \ldots \ldots
$$

The leading case involves a linear conditional mean specification, so that we have:

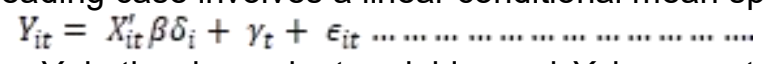

Where $Y_{i t}$ is the dependent variable, and $X_{i t}$ is a -vector of regressors, and $\epsilon_{i t}$ are the error terms fo $r i=1,2, \ldots, M$ cross-sectional units observed for dated periods $t=1,2, \ldots, \mathrm{T}$. The $\alpha$ parameter represents the overall constant in the model, while the $\delta_{i}$ and $\gamma_{t}$ represent cross-section or period specific effects (random or fixed).

A central assumption in random effects estimation is the assumption that the random effects are uncorrelated with the explanatory variables. One common method for testing this assumption is to employ a Hausman test to compare the fixed and random effects estimates of coefficients in order to determine the best model for the financial performance model. This test is also used to examine the randomness of the data distribution in this study.

Two techniques are employed in the empirical analysis of this study. These involve the use of descriptive statistics, to have a background summary measures and initial characterization of the data series. The second is the panel data estimation in order to 
investigate the influence of each of the explanatory variables on the dependent variable (ROA).

\subsection{Data Sources}

The study utilizes annual time series data mainly from the secondary sources. The underlying data for the variables of interest are obtained from the banks published annual Financial Reports at the Nigerian Stock Exchange (NSE).

\section{Empirical Results and Analysis}

\subsection{Descriptive Statistics.}

The descriptive statistics for the variables used in the analysis is presented in Table 1.

Table1: Descriptive Statistics

\begin{tabular}{|l|l|l|l|l|l|l|}
\hline & Mean & Max. & Min. & Std. Dev. & Skew & J-B \\
\hline ROA & 25.20 & 158.3 & 0.42 & 7.26 & 4.83 & 1103.2 \\
\hline CAR & 30.92 & 82.20 & 3.82 & 9.75 & 2.40 & 68.27 \\
\hline BS & 28.45 & 187.2 & 19.20 & 6.32 & 7.21 & 80.26 \\
\hline BLA & 19.02 & 243.1 & 6.34 & 9.02 & 0.48 & 25.51 \\
\hline DR & 1.85 & 7.25 & 0.27 & 2.68 & 1.92 & 65.42 \\
\hline GRGDP & 4.90 & 8.02 & -1.58 & 4.75 & 0.19 & 12.18 \\
\hline
\end{tabular}

Source: Authors' computation

The descriptive statistics shows that the mean value for ROA of return on asset for the banks is 25.20 , with maximum and minimum values of 158.3 and 7.26 percent, respectively. The standard deviation value of 7.26 shows that there is wide variability in terms of return on asset performance of the banks. Apparently, the sampled banks are dissimilar in terms of the efficiency of use of assets. The mean value of capital adequacy is 30.9 . The maximum and minimum values are 8220 and 3.42 percent, respectively. The standard deviation value is 9.50 . The mean value bank size bank loans and advances, debt ratio and growth rate of real GDP are 28.45 percent, 19.02 percent, 1.85 percent and 4.90 percent respectively. The Jacque Bera value of ROA is 11032 . In general, the data series show high skewness and kurtosis values for ROA, with significant J-B values; an indication of asymmetric distribution and non-nomality of values. The implication of this is that there is heterogeneity among the banks in terms of financial performance, using ROA. Endogeneity problem is thus expected, thus necessitating the adoption of the panel data analysis technique for the estimation of the relationships.

\subsection{Correlation Analysis}

In order to examine the nature and degree of relationship among the variables, the correlation analysis is carried out. Table 2 presents the results of the correlation matrix.

Table 2: Correlation Results

\begin{tabular}{|l|l|l|l|l|l|l|}
\hline & ROA & CAR & BS & BLA & DR & GRGDP \\
\hline ROA & & & & & & \\
\hline CAR & 0.075 & & & & & \\
\hline BS & 0.303 & -0.022 & & & & \\
\hline BLA & 0.1608 & 0.071 & 0.018 & & & \\
\hline DR & -0.028 & 0.194 & 0.202 & -0.112 & & \\
\hline GRGDP & 0.154 & 0.201 & 0.074 & 0.082 & 0.103 & \\
\hline
\end{tabular}

Source: Authors' computation 
The correlation results show that capital adequacy ratio, bank size, bank loans and advances and growth rate of real GDP are positively correlated with the return on asset of banks, while debt ratio (leverage) is negatively correlated with ROA. Given that a higher degree of correlation may lead to multi-collinearity problem, the results are reliable and tenable. The low correlation values thus implies that the performance variables are not mutually exclusive, as each is important to the determination of the financial performance of banks in Nigeria. Given the absence of excessive correlational pattern among the variables, the results become reliable. This is buttressed by the findings of Alege and Ogundipe (2013).

\subsection{Pooled OLS and Multivariate Panel Data Results}

We present the Poled OLS and Multivariate Panel Data results for the ten (10) sample banks in Table 3.

The goodness of fit for the model is not quite impressive, given the low coefficient of determination of 0.19 , which indicates that only 19 percent of the net systematic variations in the financial performance of banks (proxied by ROA) is explained by the explanatory variables; a clear indication of low explanatory and predictive power of the model. The Durbin Watson statistic shows that the estimated suffers from first order positive correlation. The coefficients of growth rate of the economy and capital adequacy ratio pass the significance test at the 1 percent and 10 percent level respectively. These results are however not surprising, given the fact that pooled OLS technique is used before conducting the Hausman test. The OLS estimates reported above cannot be relied on for policy directions, since the estimates inherently possess endogeneity issues. To address this, the panel data analysis technique is employed in re-estimating the relationships. The standard test for the method of panel analysis is to employ the Hausman to choose the appropriate method of estimation. The results of the tests for the Hausman test is reported in table 2. In the result, the Hausman test (Chi-Square statistic) of 10.52 , with a probability value of 0.03 is significant test at the 5 percent level. Thus, we reject the null hypothesis that unobserved firm specific heterogeneity is uncorrelated with regressors, and thus base our analysis on estimates provided by the fixed effect model, as the random effect estimates are likely to be biased and inconsistent. The estimates provided by the fixed effect is thus relied on for policy purpose.

In the results, the diagnostic statistics have improved significantly, compared to the OLS estimates. The adjusted R-squared value of 0.80 clearly shows that 80 percent of the net systematic variations in the financial performance of banks (indicated by ROA) are explained by the five regressors. The F- statistic of 25.3 is highly significant at the 1 percent level, and validates the existence of a significant linear relationship between the explanatory variables and the dependent variable, and suggests that the explanatory variables are jointly significant in the determination of the financial performance of the cross-sectional banks over the period. The Durbin Watson statistic of 1.70 shows that there is no serial correlation in the model, implying that the model can be used for structural and policy analysis. 
Table 3: Results from Pooled OLS and Panel Multivariate Estimation

Dependent Variable: ROA

\begin{tabular}{|c|c|c|c|c|}
\hline Variable & \multicolumn{2}{|c|}{ Pooled OLS } & \multicolumn{2}{|c|}{ Fixed Effect } \\
\hline & Coefficient & T-Ratio & Coefficient & T-Ratio \\
\hline $\mathrm{C}$ & $\begin{array}{c}0.134 \\
(0.109)\end{array}$ & 1.220 & $\begin{array}{l}1.540 \\
(1.098)\end{array}$ & 1.403 \\
\hline CAR & $\begin{array}{c}0.124 \\
(0.069)\end{array}$ & $1.782^{*}$ & $\begin{array}{l}0.1302 \\
(0.061)\end{array}$ & $2.130^{* *}$ \\
\hline BS & $\begin{array}{l}0.296) \\
(0.251)\end{array}$ & 1.178 & $\begin{array}{l}0.315 \\
(0.061)\end{array}$ & $2.431^{* *}$ \\
\hline BLA & $\begin{array}{l}0.031 \\
(0.040)\end{array}$ & 0.775 & $\begin{array}{l}0.256 \\
(0.141)\end{array}$ & $1.821^{*}$ \\
\hline DR & $\begin{array}{l}-3.067 \\
(2.405) \\
\end{array}$ & -1.275 & $\begin{array}{l}-2.202 \\
(1.374) \\
\end{array}$ & -1.402 \\
\hline GRGDP & $\begin{array}{c}1.245 \\
(0.469) \\
\end{array}$ & $2.561^{* * *}$ & $\begin{array}{l}0.727 \\
(0.195) \\
\end{array}$ & $3.721^{* * *}$ \\
\hline & & & \multicolumn{2}{|c|}{ Haussmann Test $=10.52(0.03)$} \\
\hline & \multicolumn{2}{|l|}{$\begin{array}{l}R^{-2}=0.19 \\
D W=0.98\end{array}$} & \multicolumn{2}{|c|}{$\begin{array}{l}\mathrm{R}^{-2}=0.802 \\
\mathrm{~F}-\mathrm{value}=25.3 \\
\mathrm{DW}=1.70\end{array}$} \\
\hline
\end{tabular}

${ }^{* * *}$ Statistical significance at the $1 \%$ level, ${ }^{* *}$ Statistical significance at the $5 \%$ level

* Statistical significance at the $10 \%$ level, Standard errors of coefficients in parentheses

Source: Authors' computation

In terms of the individual performance of the variables in the model, the coefficients of the independent variables are appropriately signed in line with theoretical expectations. The coefficient of capital adequacy is significant at the 5 percent level. This implies that banks' capital adequacy is significantly related to their financial performance in Nigeria, Apparently, high capital adequacy ratio tends to enhance the financial performance of banks, as it provides financial cushion to minimize incidence of liquidity crises, thereby promoting the stability, virility and efficiency of the financial system. In general, high capital sufficiency or adequacy of capital tend to prevent banks from widespread risks and other systemic crises. Thus, banks with high capital adequacy ratio face lower bankruptcy, funding costs and illiquidity problems. These have the capacity to stimulate performance. The coefficient of bank size is significant at the 5 percent level. This implies that larger banks tend to have better economies of scale in terms of financial, cost and non-pecuniary advantages that give them edge over smaller banks, particularly in terms of better growth opportunities that enhance performance. The coefficient of bank loans and advances is statistically significant at the 10 percent level. Thus, the higher the bank loans and advances granted customers, the greater the capacity of banks to make higher returns and hence, financial performance. The coefficient of leverage passes the significance test at the 10 percent level. Invariably, the higher the size of debt-ratio, the lower the financial performance of banks in Nigeria. Thus, in line with the capital structure theory, large debt stock tends to diminish the opportunity for better performance, in contrast to equity proportion. The coefficient of economic output passes the significance test at the 1 percent level. Thus, increase economic output (activities) tend to enhance bank financial performance, as greater economic output (economic activities) tend to call forth large bank transaction and services.

\subsection{Policy Implications of Findings}

A number of important implications can be deduced from the results, as follows: 
(i) Capital adequacy of banks is positively and significantly related to the financial performance of banks in Nigeria. The implication of this finding is that strong capital base that can insulate banks from fragility, arising from systemic crises, will, significantly induce greater financial performance of banks in Nigeria. The regulatory authorities should therefore ensure strong capital base for banks in order withstand any probable fragility.

(ii) Bank size has a positive and significant effect on the financial performance of banks in Nigeria. Therefore, policies that encourage sizeable bank size, particularly in terms of market shares or asset built-up place are imperative to enhancing the financial performance of banks in Nigeria.

(iii) Bank loans and advances has a positive but weak impact on the financial performance of banks in Nigeria. This requires that bank's management put in place effective and efficient policies to increase lending to the real sector of the economy. This, however should not be an overzealous policy focus, as other bank financial performance-enhancing policies and strategies are important.

(iv) Debt ratio (leverage) is negatively related to the financial performance of banks in Nigeria. The implication is that for asset management, debt pattern (structure) matter. Given a pervasive effect of debt ratio on banks' financial performance, an optimal debt-equity policy mix becomes imperative

(v) Real GDP growth rate (a measure of real output capacity) has a positive and significant effect on the financial performance of banks in Nigeria. Thus, policies to increase the productive capacity of the economy should be put in place, and in particular, stimulate economic activities, since increased economic activities will translate to increased financial services, and consequently, better financial of banks in Nigeria.

\section{Conclusion}

The importance of sound capital adequacy ratio for the stability, growth and performance of banks cannot be over-emphasized in banking architecture. Sufficient bank capital base over weighted risks (capital adequacy) has the capacity to reduce banks' vulnerability to crises. The ability of banks to minimize their vulnerability to crises lies largely in strong capital base, along with efficient deployment and management of internal assets. Without doubt, a strong, vibrant and virile banking sector is critical to efficient financial intermediation, which can support the growth of the economy. Since banks constitute the major hub of financial intermediation, there is greater imperativeness of the monetary and other regulatory authorities, particularly the $\mathrm{CBN}$ to put up strong, regulatory and effective institutional mechanisms in order to enhance bank performance and overall financial health, sustenance and stability. In the light of this, the Nigerian government and the regulatory authorities both have greater role to play in the efficient regulation and supervision of banks, particularly in the area of minimum capital adequacy in line with economic dynamics, prevailing shocks and Basel standards that will help guarantee the stability of banks. In addition, proper and efficient financial management policies in terms of lower incidence of debt ratio and sound macroeconomic policies that will stimulate the performance of the economy are imperative to enhancing the financial performance of banks, in order to galvanize their financial intermediation role for rapid economic growth.

\section{Limitation(s) of the paper}

This paper is limited by its concentration on private sector banks in Nigeria. Future studies should analyzed the effect of capital adequacy on the financial performance of public sector banks alongside private sector banks, to allow robust comparison and for all-inclusive policy prescriptions. The study is also limited by the sample size used, as larger sample size would provide more representative inferences. Enlarging the cross-section (i.e number of banks) should thus be the focus of further studies. 


\section{References}

Agbeja, O., Adelakun, O.J. and Olufemi, F. I. 2015. Capital Adequacy ratio and Bank profitability in Nigeria: A Linear Approach. International Journal of Novel Research in Marketing Management and Economics, 2 (3), pp. 91-99.

Alege, P.O. and Ogundipe, A. A. 2013. Foreign Direct Investment and Economic Growth in ECOWAS: A System-GMM Approach, Covenant Journal of Business and Social Sciences (CJBSS), 5 (1), pp. 1-22.

Boyd. J. H. and Runkle. D. E. 1993. Size and Performance of Banking Firms. Journal of Monetary Economics, 2 (3), pp.102-116.

Demirguc-Kunt, A. and Levine. R. 2000. Bank Concentrations Cross Country Evidence. McGraw-Hills Publishers, England.

Edeh, C. 2018. An Empirical Analysis of Capital Adequacy and Financial Performance of Selected Banks in Nigeria. Journal of Finance and Management, 7 (2), pp. 18-32.

Enoch, O. K. 2013. Bank Recapitalization and Lending Behavior: A Pragmatic Evidence from the Nigerian Banking Sector. Journal of Finance and Investment Analysis, 2 (4), pp. 185-195.

Ezike, J. E. and Oke, M.O. 2013. Capital Adequacy Standards, Basle Accord and Bank Performance: The Nigerian experience: A Case Study of Selected Banks in Nigeria. Asian Economic and Financial Review, 3 (2), pp.146-159.

Imala O. I. 2005. Challenges of Banking Sector Reforms \& Bank Consolidation in Nigeria. Central Bank Bullion, 29 (2).

Kumar, P. A. and Nazneen, A. 2014. An Empirical Analysis of Capital Adequacy in the Indian Private Sector Banks. American Journal of Research Communication, 2(11), pp. 28-42.

Levine, R., 1997. Financial Development and Economic Growth: Views and Agenda, Journal of Economic Literature, 35, pp. 688-726.

Levine, R. 2005. Bank-based or Market-Based Financial Systems: Which is better? Journal of Financial Intermediation, 11, pp. 398-428.

Mathur, S. 2015. A Study of Capital Adequacy Norms and its Operational Effect on Banking sector, $\mathrm{PhD}$ thesis, University of Rajasthan Jaipur (Rajasthan).

McKinnon, R.I. 1973. Money and Capital in Economic Development, Washington, DC: The Brookings Institution.

Nikhat, F. 2014. Capital Adequacy: A Financial Soundness Indicator for Banks. Global Journal of Finance and Management, 6 (8), pp. 771-776.

Olalekan, A. and Adeyinka, S. 2013. Capital Adequacy and Banks' Profitability: An Empirical Evidence from Nigeria. American International Journal of Contemporary Research, 3 (10), pp. 87-93.

Singh, Y. and Milan, R. 2018. An Empirical Analysis of Capital Adequacy Ratio and Financial Performance of Selected Banks in India. International Research Journal of Management and Commerce, 5 (3), pp. 83-95.

Torbira, L. L. and Zaagha, A. S. 2016. Capital Adequacy Measures and Bank Financial Performance in Nigeria: A cointegration Analysis. Journal of Finance and Economic Research, 3 (1), pp.15-34.

Uchendu, O. A. 2005. Banking Sector Reforms and Bank Consolidation: The Malaysian Experience in Banking Consolidation in Nigeria, Central Bank Bullion, 29 (2), pp. 45-80.

\section{Bio-note}

Arekhandia Alfred Ukinamenmen $\mathrm{PhD}$ (Finance), is a lecturer in the Department of Accounting \& Finance, Samuel Adegboyega University, Ogwa, Edo State, Nigeria. He has written several local and international papers, and attended many international conferences. 
Hassan O. Ozekhome (PhD), is a lecturer in the Department of Economics, Samuel Adegboyega University, Ogwa, Edo State, Nigeria. He holds a B. Sc (Hons) (Economics and Statistics), M.Sc (Economics) and PhD (Economics) of the University of Benin, Benin City, Nigeria. His main research interests are in Macroeconomics, Development economics, International economics, Monetary and Financial economics, and Applied econometrics. He has published widely in leading local and reputable international journals, and has participated and presented empirical research and policy papers in many international conferences and workshops. 